IJOLTL, Vol. 3, No. 1, January 2018

p ISSN: 2502 2326; e $\sim$ ISSN: 2502 8278

Http://ijolt1.pusatbahasa.or.id; Email: ijolt1@gmail.com

Center of Language and Culture Studies, Surakarta, Indonesia

Eliyawati, Rike. 2018. Using Protocols to Improve Grammatical Errors in Paragraph Writing by the Seventh Graders of SMPN 1 Karangploso. IJOLTL (2018), 3(1): 23 32.

DOI:10.30957/ijolt1.V3i1.402.

\title{
USING PROTOCOLS TO IMPROVE GRAMMATICAL ERRORS IN PARAGRAPH WRITING BY THE SEVENTH GRADERS OF SMPN 1 KARANGPLOSO
}

\author{
Rike Eliyawati \\ SMPN 1 Karangploso \\ Jl. PB Sudirman 49 Karangploso, Malang \\ Email: rikeelyawati@gmail.com
}

\begin{abstract}
Errors in auxiliary verbs have been the common problems faced by Indonesian learners to write in English. The aims of this study are to see (1) kinds of errors are identified in the modal auxiliaries the students perform, and (2) how errors are used to improve grammatical sentences in the paragraph. This study used classroom action research with two cycles. This study was done involving 32 students of class VII-A of SMPN 1 Karangploso Malang. The results show that in cycle 1, all aspects of auxiliary verbs including: to be, to do, to have, and modal were made in the error forms. In average $81.2 \%$ students made errors. In cycle 2 , the errors decline into $25 \%$. In essence $75 \%$ of paragraph developed by students after learning protocols to correct the errors have limited errors in the auxiliary verbs.
\end{abstract}

Keywords: error analysis, auxiliary verbs, protocols.

DOI: 10.30957/ijoltl.v3i1.402.

\section{INTRODUCTION}

This study is inspired by the evidences in the classroom that show how poor students' mastery in basic grammar, that is the auxiliary verbs. The low mastery is indicated by the inappropriate uses of to be, to do, to have, and modal both for oral uses or written expressions.

The basis of the analysis in this study refers to error analysis theory that emphasizes the illforms of using grammar in context. According to Dulay and Burt (1995) errors refer to incorrect use of grammatical sentences. Errors are analyzed using the criteria of correct sentences in terms of word order. In English, auxiliary verbs are the primary grammatical knowledge that every learner must master perfectly. Auxiliary verbs include: to be, to have, to do, and modal (Martinet, 1983). 
IJOLTL, Vol. 3, No. 1, January 2018

p ISSN: 2502 2326; e ISSN: 2502 8278

Http://ijolt1.pusatbahasa.or.id; Email: ijolt1@gmail.com

Center of Language and Culture Studies, Surakarta, Indonesia

Eliyawati, Rike. 2018. Using Protocols to Improve Grammatical Errors in Paragraph Writing by the Seventh Graders of SMPN 1 Karangploso. IJOLTL (2018), 3(1): 23 32.

DOI:10.30957/ijolt1.V3i1.402.

As the auxiliary verbs are very basic that influences how much a learner master the grammar of English, command in the auxiliary verbs is a must. The foundation of sentence structure in English all refer to the use of the auxiliary. The main construction of a sentence in English is subject + verb. When the verb is nit present, it should be replaced by using to be or modal auxiliaries. To change the positive sentence into negative and interrogative, the auxiliary do must apply.

Teaching grammar for SMP students is hard to do as the curriculum demands. First, teaching specific topic that solely describes the grammatical items is not allowed. Teaching grammar should be in context whether through reading passage, conversation or other contexts. Second, when context is present, it is very difficult to focus the grammar items for teaching topics. The topic needs certain time to teach and students should receive enough exercises to master. Teaching grammar in context of reading or speaking will not be appropriate for students and makes it inconvenient.

This way, the researcher initiates to improve students mastery in auxiliary verbs using protocol. Students are given a text that consists of auxiliary verb contents and they are asked to present orally. After that, students are asked to write again what they have read and performed. Identification of grammatical and ungrammatical auxiliary verbs is emphasized during the teaching sessions.

In second language acquisition, error analysis studies the types and causes of language errors. Errors are classified according to: modality (i.e., level of proficiency in speaking, writing, reading, listening) linguistic levels (i.e., pronunciation, grammar, vocabulary, style). Wikipedia describes error analysis in SLA was established in the 1960s by Stephen Pit Corder and colleagues. A key finding of error analysis has been that many learner errors are produced by learners making faulty inferences about the rules of the new language.

Error analysts distinguish between errors, which are systematic, and mistakes, which are not. They often seek to develop a typology of errors. Error can be classified according to basic type: omissive, additive, substitutive or related to word order. They can be classified by how apparent they are: overt errors such as "I angry" are obvious even out of context, whereas covert errors are evident only in context. Closely related to this is the classification according to domain, the breadth of context which the analyst must examine, and extent, the breadth of the utterance which must be changed in order to fix the error. Errors may also be classified according to the level of language: phonological errors, vocabulary or lexical errors, syntactic errors, and so on. They may be assessed according to the degree to which they interfere with communication: global errors make an utterance difficult to understand, while local errors do not. In the above example, "I angry" would be a local error, since the meaning is apparent.

Error analysis is closely related to the study of error treatment in language teaching. Today, the study of errors is particularly relevant for focus on form 
IJOLTL, Vol. 3, No. 1, January 2018

p ISSN: 2502 2326; e ISSN: 2502 8278

Http://ijolt1.pusatbahasa.or.id; Email: ijolt1@gmail.com

Center of Language and Culture Studies, Surakarta, Indonesia

Eliyawati, Rike. 2018. Using Protocols to Improve Grammatical Errors in Paragraph Writing by the Seventh Graders of SMPN 1 Karangploso. IJOLTL (2018), 3(1): 23 32.

DOI:10.30957/ijolt1.V3i1.402.

teaching methodology. According to linguist Corder (1967), the following are the steps in any typical EA research:

1. collecting samples of learner language

2. identifying the errors

3. describing the errors

4. explaining the errors

5. evaluating/correcting the errors

Collection of errors: the nature and quantity of errors is likely to vary depending on whether the data consist of natural, spontaneous language use or careful, elicited language use.

Analysis of errors has been conducted by several researchers. This way, sentences that contain auxiliary verbs are broken down in some ways, for instances: addition errors, omission errors and misformation errors. Theories of error analysis from Dulay and Burt (1983) and Brown (2000) are the main model to analyze the contexts. Budiharso (1991) conducted a research on Error analysis on the auxiliary verbs made by the first year students of SMAN 1 Samarinda. The study involved 120 students and he found that $80 \%$ of the students made errors. The profiles of errors indicate that students lack of knowledge in using to be, verbs, and modal auxiliaries. Error analysis here helps teacher project difficulties the students will face when they learn grammar. However, this study does not indicate how the errors will help students to improve their mastery in oral English.

Djulaikah (2003) conducted a research on Error analysis in the auxiliary verbs made by MAN students in Samarinda. Involving 20 students, she focuses on the variety of errors the students made in applying to do, to be and modal auxiliaries. The results replicate Budiharso's (1991) findings and no definite information is presented to profile errors for students learning. However, this study affirms that errors occur in terms of the developing process of learning to achieve mature English grammar.

With this background in mind, this study formulates its research questions as follows: (1) what kinds of errors are identified in the modal auxiliaries the students perform, and (2) how errors are used to improve grammatical sentences.

\section{METHODS}

\subsection{Design}

This study used classroom action research as the research design. The research consisted of two cycles each of which covered 2 meetings. Focus of this study was to write paragraph writing using correct grammar. This way, protocols were used as tools of teaching and grammatical errors in the protocols were 
IJOLTL, Vol. 3, No. 1, January 2018

p ISSN: 2502 2326; e ISSN: 2502 8278

Http://ijolt1.pusatbahasa.or.id; Email: ijolt1@gmail.com

Center of Language and Culture Studies, Surakarta, Indonesia

Eliyawati, Rike. 2018. Using Protocols to Improve Grammatical Errors in Paragraph Writing by the Seventh Graders of SMPN 1 Karangploso. IJOLTL (2018), 3(1): 23 32.

DOI:10.30957/ijolt1.V3i1.402.

analyzed and discussed with students. Specifically, focuses of the errors were directed to see the correct use of to be, to do, and modal auxiliaries.

\subsection{Participants}

Participants of this research were the seventh graders of SMPN 1 Karangploso Malang. The number of graders were 32 students sitting in the VIIA class. All students in the VII-A were assigned as research subject and participated in this research. Participants hade received materials of grammar for to be, to do, and modal auxiliaries since the first semester. Participants were assured to have enough explanation and exercises on the auxiliary verbs topic.

\subsection{Procedures}

Data of this research consisted of typical errors written in the protocols and in the paragraph writing. Procedures of the research were as follows. First, students were assigned to read a text then each student were asked to rewrite the contents they memorized on a piece of paper. Second, students were asked to identify kinds of auxiliary verbs they produced in the paper. Kinds of auxiliary verbs were analyzed their errors. This was done for three times. Third, students were asked to write a paragraph on the topic the teacher had set. The paragraph the students wrote then was analyzed its sentences that focused on the use of auxiliary verbs. This was done twice. Fourth, students were asked to write a god paragraph with caution to apply auxiliary verbs correctly. In this session, students were involved to correct their own paragraphs by administering the errors in auxiliary verbs they produced in the paragraphs. These four steps were done in the cycle 1 and cycle 2 .

Data were identified in two forms: typical errors presented in a sentence the students wrote in the paragraph, and progress achievement from cycle 1 to cycle 2. If number of students making errors declined, more correct sentences appeared. Number of students was rated and their scores were identified.

\subsection{Data Analysis Techniques}

Data of this study were paragraph writing. There were two kinds of paragraph the students wrote for analysis. The first paragraph was obtained from cycle 1 and the second was gained from cycle 2. Each paragraph in each cycle was scored. After scoring was given, each paragraph was identified its features of auxiliary verbs; sentences that contained the auxiliary verbs were recorded to see their correct or incorrect uses of the auxiliary. Features of auxiliary verbs appearing in the first paragraphs were tabulated and the cores were rated. The results indicated the gains in the cycle 1. In addition, scores and features of auxiliary verbs in the paragraph 2 indicated the accomplishments in the cycle 2 . 
IJOLTL, Vol. 3, No. 1, January 2018

p ISSN: 2502 2326; e ISSN: 2502 8278

Http://ijolt1.pusatbahasa.or.id; Email: ijolt1@gmail.com

Center of Language and Culture Studies, Surakarta, Indonesia

Eliyawati, Rike. 2018. Using Protocols to Improve Grammatical Errors in Paragraph Writing by the Seventh Graders of SMPN 1 Karangploso. IJOLTL (2018), 3(1): 23 32.

DOI:10.30957/ijolt1.V3i1.402.

\section{FINDINGS AND DISCUSSION}

\subsection{Kinds of Typical Errors on Auxiliary Verbs}

Kinds of typical errors on auxiliary verbs obtained in this study were of three kinds: omission errors, addition errors (double marking and regularization) and misformation.

\section{1) Omission}

Omission errors are characterized by the absence of an item that must appear in a well-formed utterance. Types of data obtained from the test are exemplified in script (1).

(1) *She not give her a gift? (A-A.II-7)

*Did Rima and Maya the homeworks two hours ago? (B-A.II-8)

*The students have at school. (S-B-2)

The sentences above are wrong because these are some parts of sentences that missing. The right reconstructions of the sentences are presented in (1a).

(1a) Does she give her a gift?

Did Rima and Maya do the home works two hours ago?

The students have been at school.

\section{2) Additions}

Additions errors are characterized by the presence of an item which must not appear in a well-formed utterance. Errors on addition are (1) double marking, (2) regularization, and (3) mis-formation.

\section{a) Double Marking}

Many addition errors are more accurately described as the failure to delete certain items which are required in some linguistic construction. Types of data obtained from the test are in script (2):

(2) *I am have been the consumer of the product for a long time.

(O-B: 11)

The sentence above is wrong because the students add unnecessary parts of utterance. The right reconstruction of the sentence is as follows:

(2a) I have been the consumer of the product for a long time. 
IJOLTL, Vol. 3, No. 1, January 2018

p ISSN: 2502 2326; e ISSN: 2502 8278

Http://ijolt1.pusatbahasa.or.id; Email: ijolt1@gmail.com

Center of Language and Culture Studies, Surakarta, Indonesia

Eliyawati, Rike. 2018. Using Protocols to Improve Grammatical Errors in Paragraph Writing by the Seventh Graders of SMPN 1 Karangploso. IJOLTL (2018), 3(1): 23 32.

DOI:10.30957/ijolt1.V3i1.402.

\section{b). Regularization}

A rule typically applies to a class of linguistic items, such as the class of main verbs or the class of nouns. Types of data obtained from the test are as follows:

1. My friends didn't usually come to my house on Sunday. (B - A.I : 1)

2. The woman usually don't open her shop at 08.00 a.m. (O - A.I : 2)

3. Does the students always learn at 07.30 a.m.? (G - A.II : 4)

The sentences above are wrong because the students add unnecessary parts of utterance. The right reconstructions of the sentences are as follows:

1. My friends don't usually come to my house on Sunday.

2. The woman doesn't usually open her shop at 08.00 a.m.

3. Do the students always learn at 07.30 a.m.?

\section{c) Misformation}

Misformation errors are characterized by the use of the wrong form of the morpheme or structure. Types of data obtained from the test are as follows:

1. The students weren't follow the flag ceremony every Monday. (N-A.I : 3)

2. I wasn't see her at SCP mall last night. (I-A.I : 4)

3. Mariana Renata wasn't sing a song beautifully last Sunday. (H-A.I : 7)

The sentences above are wrong because those sentences are not constructed in well-formed structures. The right reconstructions of the sentences are as follows:

1. The students don't follow the flag ceremony every Monday.

2. I didn't see her at SCP mall last night.

3. Mariana Renata didn't sing a song beautifully last Sunday.

The analysis of the students' errors present on auxiliary verbs are also tended on the students' errors on three items of auxiliary verbs. The three items of auxiliary verbs are: 1) to do (do, does, did), 2) to have (have, has), 3) modal auxiliary (can, could, will, would, may, must). The results of analysis are presented on Table 1. 
IJOLTL, Vol. 3, No. 1, January 2018

p ISSN: 2502 2326; e $\sim$ ISSN: 2502 8278

Http://ijolt1.pusatbahasa.or.id; Email: ijolt1@gmail.com

Center of Language and Culture Studies, Surakarta, Indonesia

Eliyawati, Rike. 2018. Using Protocols to Improve Grammatical Errors in Paragraph Writing by the Seventh Graders of SMPN 1 Karangploso. IJOLTL (2018), 3(1): 23 32.

DOI:10.30957/ijolt1.V3i1.402.

Table 1 Summary of Errors types in this research

\begin{tabular}{|c|c|c|}
\hline No. & Item of Test & Students' Errors \\
\hline \multirow[t]{5}{*}{1.} & To Do & \\
\hline & a. Do & My friends doesn't come to my house on Sunday \\
\hline & b. Does & The woman usually don't open her shop at 08.00 a.m. \\
\hline & & $\begin{array}{l}\text { Mariana Renata doesn't sing a song beautifully last } \\
\text { Sunday }\end{array}$ \\
\hline & c. Did & I don't see her at SCP mall last night \\
\hline \multirow[t]{3}{*}{2.} & To Have & \\
\hline & a. Have & $\begin{array}{l}\text { I has studied many subjects in this course } \\
\text { I am have been the consumer of the product for a long } \\
\text { time }\end{array}$ \\
\hline & b. Has & $\begin{array}{l}\text { My mother have been friendly, patient, and beautiful } \\
\text { woman }\end{array}$ \\
\hline \multirow[t]{8}{*}{3.} & $\begin{array}{l}\text { Modal } \\
\text { Auxiliary }\end{array}$ & \\
\hline & a. Can & $\begin{array}{l}\text { Tina : Excuse me, must I to try the blue one? } \\
\text { Shopkeeper: Yes, try in the fit room. }\end{array}$ \\
\hline & b. Could & I looked for my book but I can't find it \\
\hline & & $\begin{array}{l}\text { She can't speaks English well when she was } 5 \text { years } \\
\text { old, but she cans speak English fluently now. }\end{array}$ \\
\hline & c. Will & $\begin{array}{l}\text { Must you gives me a cup of coffee? } \\
\text { Meira would goes to Canada for her holiday. }\end{array}$ \\
\hline & d. Would & May you like some orange juice? \\
\hline & e. May & $\begin{array}{l}\text { Must I to come in, sir? } \\
\text { Will I to borrow your pen to sign this letter? }\end{array}$ \\
\hline & f. Must & - \\
\hline
\end{tabular}

\subsection{Implementation of Error Corrections in Writing}

\subsubsection{Error Correction in Cycle 1}

Error correction in cycle 1 applies for $80 \%$ of the subjects and all aspect of auxiliary verbs appear in the illforms. Table 2 shows characteristics of errors in this study. 
IJOLTL, Vol. 3, No. 1, January 2018

p ISSN: 2502 2326; e $\sim$ ISSN: 2502 8278

Http://ijoltl.pusatbahasa.or.id; Email: ijolt1@gmail.com

Center of Language and Culture Studies, Surakarta, Indonesia

Eliyawati, Rike. 2018. Using Protocols to Improve Grammatical Errors in Paragraph Writing by the Seventh Graders of SMPN 1 Karangploso. IJOLTL (2018), 3(1): 23 32.

DOI:10.30957/ijolt1.V3i1.402.

Table 2. Characteristics of Errors in Cycle 1

\begin{tabular}{|c|c|c|c|}
\hline No & Kinds of error & $\begin{array}{l}\text { Frequency of error } \\
(\mathrm{N}=32)\end{array}$ & Percentage \\
\hline 1 & To be & 28 & 87.5 \\
\hline 2 & To do & 31 & 96.9 \\
\hline 3 & To have & 25 & 78.1 \\
\hline 4 & Modal & 20 & 62.5 \\
\hline & Total & 104 & 325 \\
\hline & Average & 26 & 81.3 \\
\hline
\end{tabular}

As table 2 suggests, level of difficulty of the auxiliary verbs is indicated by the rate percentage. In all most students made errors in each kind of auxiliary, indicating that students do have problems in mastery the auxiliary verbs. Modal auxiliary receives $62.5 \%$ of difficulty, and the most difficult is indicated by the mastery of "to do auxiliary" as $96.7 \%$ students made errors. Respectively, level of difficulty of the errors is (1) modal $62.5 \%$, (2) to have $78.1 \%$, (3) to be $87.5 \%$, and to do $96.9 \%$. In average 26 or $81.3 \%$ students made errors. This means auxiliary verbs are considered difficult so that $81.3 \%$ students made errors in all aspects of auxiliary verbs.

Achievement on the scores of paragraph that contain errors in vocabulary is indicated in table 3 .

Table 3. Scores of paragraph achievement in cycle 1

\begin{tabular}{|l|l|l|l|l|}
\hline No & Range of score & Frequency & $\%$ & Status \\
\hline 1 & $86-100$ & 0 & 0 & \\
\hline 2 & $76-85$ & 2 & 6.3 & Good \\
\hline 3 & 75 & 4 & 12.5 & Good (minimum standard) \\
\hline 4 & $66-74$ & 18 & 56.3 & Moderate \\
\hline 5 & $10-65$ & 8 & 25 & Low \\
\hline & & 32 & 100 & \\
\hline
\end{tabular}

As table 3 indicates the minimum standard of achievement 75 is achieved by $4(12.5 \%)$ students. With students achieving good qualification 2 (6.3\%), students in cycle 1 who achieved successfulness are 6 or $18.8 \%$. This means in efforts to increase students performance in paragraph writing that have errors in auxiliary verbs ar4e not successful. The results are confirmed with the achievement of errors in general as seen in Table 2. 
IJOLTL, Vol. 3, No. 1, January 2018

p ISSN: 2502 2326; e $\sim$ ISSN: 2502 8278

Http://ijolt1.pusatbahasa.or.id; Email: ijolt1@gmail.com

Center of Language and Culture Studies, Surakarta, Indonesia

Eliyawati, Rike. 2018. Using Protocols to Improve Grammatical Errors in Paragraph Writing by the Seventh Graders of SMPN 1 Karangploso. IJOLTL (2018), 3(1): 23 32.

DOI:10.30957/ijolt1.V3i1.402.

\subsubsection{Error correction in Cycle 2}

Improvement in eliminating errors in cycle 2 declines as indicated in Table 4. Progress is achieved in to be and to do, meaning most students understand he correct uses nominal and verbal sentences.

Table 4. Error correction in auxiliary verbs

\begin{tabular}{|c|c|c|c|}
\hline No & Kinds of error & $\begin{array}{l}\text { Frequency of error } \\
(\mathrm{N}=32)\end{array}$ & Percentage \\
\hline 1 & To be & 9 & 28.1 (71.9 correct $)$ \\
\hline 2 & To do & 10 & $31.3(68.7)$ \\
\hline 3 & To have & 6 & $18.8(81.2)$ \\
\hline 4 & Modal & 6 & $18.8(81.2)$ \\
\hline & Total & 31 & 97 \\
\hline & Average & 8 & 24.3 \\
\hline
\end{tabular}

Data on Table 4 shows that frequency of errors declines substantially. In average only 8 students made errors and the rate percentage of errors is $24.3 \%$. To be and to do that in cycle 1 are hard for students, in the cycle 2 the materials are solved until $71.9 \%$ for to be and $68.7 \%$ for to do. To have and modal are much easier as indicated by the rate percentage of correct answer up to $81.2 \%$ each. This means protocols to improve errors in auxiliary verbs give better improvement.

To make sure if improvement is significant, scores on paragraph writing with limited errors in auxiliary verbs are presented in Table 5.

Table 5. Scores of paragraph writing with limited errors in auxiliary verbs.

\begin{tabular}{|l|l|l|l|l|}
\hline No & Range of score & Frequency & $\%$ & Status \\
\hline 1 & $86-100$ & 5 & 16.6 & Very good \\
\hline 2 & $76-85$ & 8 & 25 & Good \\
\hline 3 & 75 & 11 & 36.7 & Minimum standard \\
\hline 4 & $66-74$ & 6 & 18.8 & Moderate \\
\hline 5 & $10-65$ & 2 & 6.3 & Low \\
\hline & & 32 & 100 & \\
\hline
\end{tabular}

Table 5 suggests that the distribution of scores is equal giving proportion the successful students that are identified from those who achieved minimum standard, good and very good are 24 or $75 \%$. Students who were failed are 8 or $25 \%$. It is evident that protocols to correct errors in auxiliary verbs in the cycle 2 produce satisfied results. 
IJOLTL, Vol. 3, No. 1, January 2018

p ISSN: 2502 2326; e $\sim$ ISSN: 2502 8278

Http://ijolt1.pusatbahasa.or.id; Email: ijolt1@gmail.com

Center of Language and Culture Studies, Surakarta, Indonesia

Eliyawati, Rike. 2018. Using Protocols to Improve Grammatical Errors in Paragraph Writing by the Seventh Graders of SMPN 1 Karangploso. IJOLTL (2018), 3(1): 23 32.

DOI:10.30957/ijolt1.V3i1.402.

Considering results in cycle 1 that most students made errors in all aspects of auxiliary verbs and improvement that reduce the errors in cycle 2 this study evidently contends that protocols to reduce errors in auxiliary verbs are successful.

\section{CONCLUSION}

This study aims to see kinds of errors in auxiliary verbs and process of improvement how protocols are applicable to reduce errors in paragraph writing. Major conclusion of this study states that in cycle 1 when students initially apply protocols to reduce errors in auxiliary verbs students do face problems in understanding auxiliary verbs to write paragraph. Students made errors in terms of to be, to do, to have and modals. In average students made errors up to $81.3 \%$. Specifically, after protocols are implemented in second cycle, students error decline in the average of $81.2 \%$. Surprisingly, to be and to do that are considered difficult topic have been made easy in the cycle 2 . This finding is limited into its scope and applicability. It is limited that the research subject is only 32 graders of SMPN 1 Karangploso and the applicability is restricted in the class VII-A. Future research is directed to expand the research subjects in number and schools and develop the errors in syntax level, e.g. sentence and paragraphs.

\section{REFERENCES}

Association of English Teachers of Vocational High School East Java. 2005.

English Module Applicable for Communicative \& Contextual Learning (Completed with TOEIC Exercises). Malang: Vocational High School of East Java.

Bogdan, Robert C. and Knopp Biklen, Sari. 1998. Qualitative Research for Education. An Introduction to Theory and Methods. New York: A Viacom Company.

Budiharso, Teguh. 1990. Error Analysis on Auxiliary Verbs and Ordinary Verbs (A Case Study of the First Year Students of the SMA 2 Negeri Samarinda). Samarinda: College of Education, Mulawarman University.

Budiharso, Teguh. 2006a. Introduction to Qualitative Research in Education. Tenggarong: School of Teacher Training and Education, University of Kutai Kartanegara.

Budiharso, Teguh. 2006b. English Language in Teaching Discourse Analysis, and Contrastive Rhetoric. Samarinda: Certel Books.

Djiwandono, M. Soemardi. 1996. Tes Bahasa dalam Pengajaran. Bandung: Penerbit ITB

Dulay, Heidi, Burt, Marina and Krashen, Stephen. 1982. Language Two. Oxford: Oxford University Press. 